\title{
Extracts of Caesalpinia ferrea and Trichoderma sp. on the control of Colletotrichum sp. transmission in Sideroxylon obtusifolium seeds
}

\author{
MELO, P.A.F.R. ${ }^{*}$; ALVES, E.U. ${ }^{2 ;}$ MARTINS, C.C. ${ }^{1 ;}$ ANJOS NETO, A.P. ${ }^{2} ;$ PINTO, K.M.S..; ARAÚJO, L.R. ${ }^{2}$; \\ VIEIRA, C.P. ${ }^{2 ;}$ NASCIMENTO, L.C. ${ }^{2}$ \\ Universidade Estadual Paulista - UNESP, via de Acesso Prof. Paulo Donato Castellani, s/n, CEP. 14884-900, \\ Jaboticabal, SP, Brasil. 2Universidade Federal de Paraíba - UFPB, Rodovia PB-079, CEP. 58397-000, Areia, \\ PB, Brasil. *Autor para correspondência: pauloalexandrefernandes@outlook.com
}

\begin{abstract}
Recent research reports the importance of preserving plants in Brazilian semiarid regions, in this context, the scientific literature has reported different pharmacological studies from plant extracts with an antifungal potential, coming from forest species that can contribute as a control and management strategy in the transmission of phytopathogens. This study aimed to evaluate the effect of biotech treatments in controlling the transmission of Colletotrichum sp. in seeds of S. obtusifolium. In this study, 100 seeds were subjected to the following preventive treatments: fungicide Captan ${ }^{\circledast}$, extract of Caesalpinia ferrea Mart. Ex. Tul., and biological control with Trichoderma spp. The biological control with Trichoderma spp. and the alternative control using $C$. ferrea extract provided a greater protection to seeds and seedlings of $S$. obtusifolium facing the transmissibility of Colletotrichum sp. The treatment based on plant extract is more efficient for this purpose only in large seeds and does not interfere on the germination percentage and speed. Therefore it is necessary to perform other studies with Trichoderma spp. and C. ferrea extract to test different doses of these products.
\end{abstract}

Key words: Bumelia sertorium, Libidibia ferrea, vegetal extract and phytopathogens.

\begin{abstract}
RESUMO: Extratos de Caesalpinia ferrea e Trichoderma spp. no controle da tramissibilidade de Colletotrichum sp. em sementes de Sideroxylon obtusifolium (Sapotaceae). Recentes pesquisas relatam a importância da preservação de plantas do semiárido brasileiro. Neste contexto, a literatura científica tem relatado diferentes estudos farmacológicos com extratos vegetais com potencial antifúngico proveniente de espécies florestais que podem contribuir como estratégia de controle e gerenciamento na transmissão de fitopatógenos. No presente estudo o objetivo foi avaliar o efeito de tratamentos biotecnológicos no controle da transmissibilidade de Colletotrichum sp. em sementes de S. obtusifolium. Neste estudo foram utilizadas 100 sementes submetidas aos seguintes tratamentos preventivos: fungicida Captan ${ }^{\circledR}$, extrato de Caesalpinia ferrea Mart. Ex. Tul. e controle biológico com Trichoderma spp. O controle biológico com Trichoderma spp. e o alternativo com extrato de $C$. ferrea proporcionam maior proteção às sementes e plântulas $S$. obtusifolium quanto a transmissibilidade do Colletotrichum sp. $O$ tratamento à base de extrato vegetal foi o mais eficiente para este fim, apenas em sementes de maior tamanho, por não interferir na porcentagem e velocidade de germinação. Portanto, faz-se necessário à realização de outros trabalhos com Trichoderma spp. e extrato de C. ferrea para testar doses diferentes desses produtos.
\end{abstract}

Palavras-chave: Bumelia sertorium, Libidibia ferrea, extrato vegetal e fitopatógenos.

\section{INTRODUCTION}

Sideroxylon obtusifolium (Roem \& Schult.) Penn. is a specie of the caatinga biome that because of intense use, it is at risk of local extinction in the Northeast of Brazil (Silva \& Dantas, 2013). This species is popularly known as quixaba, sapotiaba, sacutiaba, coronilha, coca, miri, rompe-ribão, but it is not a cultivated fruit (Silva et al., 2012a), however, it is widely utilized in the medicine due to its phytotherapeutic properties, which indicate the presence of some compounds of pharmacological 
interest (Gomes et al., 2010). This way, the establishment of forest recovery programs through the production of seedlings from seeds quality and genetic variability is essential (Beltrão et al., 2008). In this context, the sanity and physiological quality of seeds becomes important once the production of seedlings from them will reflect on their ability to develop healthy plants (Mondego et al., 2014).

The germination capacity it affected by the presence of fungi, as they serve up the seeds as a vehicle for transport and as shelter for survival, and thus involved in the continuity of the life cycle of these pathogens from one to another generation of the host plant. Thus, the research associated with transmission the seed and seedling contributes to defining certain control strategies involving the management of disease, since it thus defines if the inoculum of causative agent reached new areas through seed transmission or other random and pathway of foci of fungal infection (Poletto et al., 2014).

In this context, among the fungi associated with seeds, in Brazil there are about 59 genus of the Colletotrichum sp. fungi. This pathogen has been present in 154 host plants, among them, forest seeds as Lithraea brasiliensis March., Myracrodruon urundeuva Fr. All., Tabebuia impetiginosa Mart. ex DC. Standl., Apeiba tibourbou Aubl., Cedrela fissilis Vell., Dalbergia nigra Vell., may cause root seeds, leaf spots, low germination and seedling damaged when detected a high incidence (Vechiato \& Parisi, 2013).

However, there is still a lack of research regarding the condition of forest seeds and the efficiency of chemical and alternative products, for the implementation of sanitary methods in the production of tree nurseries (Mertz et al., 2009). In this context, the scientific literature has reported different pharmacological studies (Marreiro et al., 2014), from plant extracts with antifungal potenticiality, coming from forest species, among them Caesalpinia ferrea Mart. Ex. Tul. which is an endemic species of north and northeast in Brazil (Ferreira \& Soares, 2015). Therefore, become necessary research to find new bioactive molecules with relevance in the control of pathogens because it was believed that it is difficult to develop resistance to these compounds present in plant extracts with components that differ as fromtheir mode of action and apparently from their chemical constitution (Ferreira et al., 2013).

Moreover, taking into consideration the great potential of using $S$. obtusifolium in reforestation, ecology and pharmaceutical industry (Oliveira et al., 2012), the present study aimed to evaluate the effect of biotechnological treatments in controlling transmission of Colletotrichum sp. in seeds of Sideroxylon obtusifolium (Roem \& Schul.) Penn.

\section{MATERIALS AND METHODS}

\section{Obtaining seeds}

This study was conducted using $S$. obtusifolium seeds which were harvested from fully mature fruits from six mother tree that were located in Boa Vista, PB, in the first half of February 2013. The mother trees were geographically located at the following coordinates: $\mathrm{M}_{1}: 7^{\circ} 13^{\prime} 51^{\prime \prime}$ $S$ and $36^{\circ} 14^{\prime} 02^{\prime \prime} W ; M_{2}: 7^{\circ} 13^{\prime} 48^{\prime \prime} S$ and $36^{\circ} 14^{\prime} 01^{\prime \prime}$ W; $M_{3}: 7^{\circ} 14^{\prime} 24^{\prime \prime} S$ and $36^{\circ} 14^{\prime} 18^{\prime \prime}$ W; $M_{4}$ : $7^{\circ} 14^{\prime} 30^{\prime \prime}$ $S$ and $36^{\circ} 15^{\prime} 19^{\prime \prime} \mathrm{W} ; \mathrm{M}_{5}: 7^{\circ} 13^{\prime} 42^{\prime \prime} \mathrm{S}$ and $36^{\circ} 14^{\prime}$ 02 " W; $M_{6}: 7^{\circ} 13^{\prime} 40^{\prime \prime} S$ and $36^{\circ} 14^{\prime} 01^{\prime \prime} \mathrm{W}$ and the local has an average altitude of 490 meters.

After harvesting, the fruits were placed in polyethylene bags and taken to the Laboratory of Seed Analysis (LSA) and Plant Pathology of the phytotechnic and environmental Sciences Department, at the Agricultural Science Center of the Federal University of Paraiba, where the experiments were conducted. The fruits were underwent to natural fermentation for 72 hours, after this period they were rinsed in running water to obtain the seeds which were dried on paper towels at indoor temperature at the laboratory environment $\left(25 \pm 2{ }^{\circ} \mathrm{C}\right)$ for 72 hours (Silva et al., 2012a).

\section{Length and Seed moisture content}

Initially, the seed samples in each lot (mother trees trees) were measured using a digital caplier $(0.001 \mathrm{~mm})$ to determine length. The biometric data associated with the length of the seeds from the different mother trees $\left(M_{1}-9.99\right.$ $\mathrm{cm}, \mathrm{M}_{2}-9.94 \mathrm{~cm}, \mathrm{M}_{3}-7.69 \mathrm{~cm}, \mathrm{M}_{4}-7.51 \mathrm{~cm}, \mathrm{M}_{5}$ $-7.45 \mathrm{~cm}$ and $M_{6}-6.54 \mathrm{~cm}$ ) served as a basis for obtaining the initial quality of the samples. The water content was obtained by using the oven method at $105^{\circ} \mathrm{C}$ for $24 \mathrm{~h}$, with four replications of 25 seeds per mother tree in each seed lot and was carried out according to the Rules for Seed Testing (Brasil, 2009).

\section{Sanitary test}

To identify the microflora in seeds it was used the filter paper method (Blotter Test), with 200 seeds of each mother tree divided into eight replicates of 25 seeds subjected to surface disinfection by immersion in sodium hypochlorite at $2 \%$ for five minutes and then placed in petri dishes with sterile filter paper moistened with sterile distilled water. After a seven day incubation period at indoor temperature $\left(25 \pm 2{ }^{\circ} \mathrm{C}\right)$, fungal structures were analyzed with the aid of stereoscopic and optical microscope. Confirmation of fungi genus level was performed using an identification key (Barnett \& Hunter, 1972). 


\section{Obtaining the inoculum and the crude alcoholic extract (CAE)}

After evaluating the microflora of seeds of S. obtusifolium we observed the following average incidence of fungal genera: Aspergillus niger (11\%), Aspergillus flavus (1\%), Aspergillus sp. (3\%), Botrytis sp. $(0.2 \%)$, Colletotrichum sp. (2\%), Chaetonium sp. $(0.6 \%)$, Cladosporium sp. (0.1\%), Curvularia sp. $(0.4 \%)$, Fusarium sp. (0.8\%), Helminthosporium $(0.1 \%)$, Nigrospora sp. $(0.2 \%)$. Data referring to fungal incidence was not statistically analyzed, only served as a basis for the initial knowledge of the quality of the samples, which is the first report of fungi associated to this forest species.

Although for the Colletotrichum sp. has found moderate incidence, according to Vechiato \& Parisi (2013), nothing can be stated in regard to the damage that can be caused, given there is no search results on transmission rates that can quantify the damage to forest seeds. Thus we proceeded to obtain the isolates of Colletotrichum sp. following the methodology described by Medeiros et al. (2013), where the seeds were incubated in petri dishes containing PDA medium (1000 ml of distilled water, $200 \mathrm{~g}$ of potato, $20 \mathrm{~g}$ dextrose and $17 \mathrm{~g}$ agar) sterilized.

After seven days of incubation period at indoor temperature $\left(25 \pm 2{ }^{\circ} \mathrm{C}\right.$ and a $12 \mathrm{~h}$ photoperiod), the fungal structures were analyzed with the aid of a stereoscopic and optical microscope. The fungus (Colletotrichum sp.) was isolate and replicated in petri dishes containing sterilized PDA medium, following the method described previously by Medeiros et al. (2013) and then the genera of the pathogen was confirmed using identification keys (Barnett \& Hunter, 1972).

The C. ferrea leaves, a species of the Fabaceae Caesalpiniaceae family, known as juca, jucaina and pau-ferro (Brazilian ironwood), was collected at the Agricultural Science Center of the Federal University of Paraiba, Areia, PB, geographically located at the coordinates $6^{\circ} 57^{\prime} 42^{\prime \prime}$ $\mathrm{S}, 35^{\circ} \mathbf{4 1} \mathbf{4 3}^{\prime \prime} \mathrm{W}$, and used to obtain the crude alcoholic extract (CAE). They were collected and placed in Kraft paper bags and then taken to the LSA where they were weighed on a precision scale $(0,001 \mathrm{~g})$ and put into portions of $500 \mathrm{~g}$ each.

Shortly after, the leaves were sterilized for five minutes using a solution of sodium hypochlorite $(2 \%)$ and then they were oven dried at a temperature of $40{ }^{\circ} \mathrm{C}$ for a period of 72 hours and completely grindded using an electric grinder until no pieces of intact leaves were visible (Stange et al., 2009). The CAE was obtained as described by Silva et al. (2012b) with slight modifications, where $60 \mathrm{~g}$ of the ground leaves were infused in $700 \mathrm{~mL}$ of absolute alcohol (99.5\%) and left at indoor temperature for
$24 \mathrm{~h}$. After extraction, the extract was filtered at a temperature of $50{ }^{\circ} \mathrm{C}$ and taken to the vacuum evaporator (Biothec ${ }^{\circledR}$ Model BT 350/4) to remove the solvent, the residue was then stored in previously sterilized and dried amber bottles with lids.

\section{Seed treatment and inoculation}

The concentration of the fungal suspension was determined using a Neubauer chamber with about $2 \times 10^{5}$ conidia/mL of Colletotrichum sp., in which the seeds from each mother tree were inoculated by immersing them in the same fungal suspension for a $12 \mathrm{~h}$ period with four replications of 25 seeds. The seeds were kept at indoor temperature $\left(25 \pm 2^{\circ} \mathrm{C}\right)$ and dried on paper towels for 30 minutes, they were then disinfected with sodium hypochlorite $(2 \%)$ for two minutes and $70 \%$ ethanol for 30 seconds, afterwards they were rinsed twice in sterile distilled water (SDW) and dried as previously described (Ferraz \& Calvi, 2010). The treatments were composed by $\left(T_{1}\right)$ untreated and no inoculated seeds, $\left(T_{2}\right)$ seeds inoculated with Colletotrichum sp., $\left(\mathrm{T}_{3}\right)$ inoculated seeds treated with Captan ${ }^{\circledR}$ fungicide, $\left(T_{4}\right)$ inoculated seeds treated with $C$. ferrea extract and $\left(\mathrm{T}_{5}\right)$ inoculated seeds treated with Trichoderma spp.

The chemical treatment was carried out manually, by applyinng the fungicide Captan ${ }^{\circledR}$ at a concentration of $240 \mathrm{~g}$ per $100 \mathrm{~kg}$ of seeds, subsequently, the seeds were placed in a polyethylene plastic bag and shaken until homogeneous. The biological and alternative treatments were conducted by immersing the seeds for a $24 \mathrm{~h}$ period in $20 \mathrm{~mL}$ of the bio-fungicide Trichodel ${ }^{\oplus}$, the dosage used was based on the manufacturer recommendations, $1 \mathrm{x}$ $10^{9}$ viable cells per milliliter of Trichoderma spp. and the $C$. ferrea extract was diluted at a ratio of $0.156 \mathrm{mg}$ per $200 \mathrm{~mL}$, this dosage was based on preliminary tests using SDW.

\section{quality}

\section{Evaluation of physiological and sanitary}

The evaluation of the physiological and sanitary quality (transmissibility) was performed mutually in a germination chamber at a constant temperature of $30{ }^{\circ} \mathrm{C}$ with a $12 \mathrm{~h}$ light/ $12 \mathrm{~h}$ dark period using fluorescent lights $(4 \times 20 \mathrm{~W})$. Initially, the seeds were manually scarified with 80 grit sandpaper on the opposite side of the hilum region and sown in transparent plastic boxes $(11.0 \times 11.0 \times 3.5 \mathrm{~cm})$ which were sterilized with sodium hypochlorite $(2 \%)$ containing vermiculite substrate (Silva et al., 2012a), they were then moistened with distilled water at $60 \%$ of its retention capacity (Brasil, 2009) with four repetitions of 25 seeds per treatment, the seeds were placed in substrate at a depth of two centimeters.

The evaluations were performed every

Rev. Bras. PI. Med., Campinas, v.18, n.2, p.494-501, 2016. 
other day from the 15th to the 30 th day, taking as a criterion the seedling emergence and the results are expressed in percentages. On the 30th day, the final transmissibility test was performed using the seeds submitted to the last four treatments $\left(T_{2}\right)$ seeds inoculated with Colletotrichum sp., $\left(T_{3}\right)$ inoculated seeds treated with Captan ${ }^{\circledast}$ fungicide, $\left(T_{4}\right)$ inoculated seeds treated with $C$. ferrea extract and $\left(\mathrm{T}_{5}\right)$ inoculated seeds treated with Trichoderma spp. previously described. The incidence of the disease in the inoculated $S$. obtusifolium seeds was determined as well as the rates of infection and transmission in shoots and primary roots associated to Colletotrichum sp..

During this period, plants that showed Colletotrichum sp. infection symptoms in the cotyledons, roots, stems or leaves were considered sick plants. To confirm the etiology of the pathogen, symptomatic seeds, seedling fragments and roots were previously sterilized according to the method described by Walker et al. (2013) and Mondego et al. (2014) and were incubated in Petri dishes containing sterilized PDA medium (1000 mL of distilled water, $200 \mathrm{~g}$ of potato, $20 \mathrm{~g}$ of dextrose and $17 \mathrm{~g}$ of agar).

After a seven day incubation period at indoor temperature $\left(25 \pm 2{ }^{\circ} \mathrm{C}\right)$ and a $12 \mathrm{~h}$ photoperiod, the fungal structures were analyzed with the aid of a stereoscopic and optical microscope. The genera of the fungus were obtained using identification keys (Barnett \& Hunter, 1972), the transmission of the pathogen to the emerged plant and to the dead non-emerged seedlings was considered positive when at least one seed, fragment of the symptomatic or asymptomatic plant presented mycelial growth.

At the end of the germination test, the percentage (Labouriau, 1983) and germination speed index (Maguire, 1962) was determined, the rate of transmission of the fungus to the seedlings was calculated using the formula adapted from Teixeira \& Machado (2003): T(\%) = I.T $(\%) \times 100 /$ I.D(\%), where I.T = infection rate in seedlings with symptoms of the selected fungus; I.D = incidence of disease in artificially inoculated seeds.

\section{Experimental design and statistical analysis}

The experiment was conducted in an entirely randomized design, with treatments distributed in a 6 $x 5$ factorial arrangement for the physiological quality (six mother trees and five treatments), and a $6 \times 4$ factorial arrangement for the sanitary quality analysis (six mother trees and four treatments), both with four replications of 25 seeds. Data were subjected to the variance analysis test (ANOVA) using the SAS ${ }^{\circledR}$ statistical software (Statistical Analysis System) and means were compared by Tukey test at $1 \%$ probability (SAS/STAT, 2011).

\section{RESULTS AND DISCUSSION}

The moisture content of the S. obtusifolium seeds were about $10 \%$, and the higher percentages of germination (Table 1) occurred in the seeds that did not receive treatment and were not inoculated (Rate of germination (\%) $=M_{1}-95, M_{2}-90, M_{3}-93$, $M_{4}-92$ and $M_{6}-88$ ), associated with all mother trees except for mother tree 5 (85\%). However, these did not differ statistically $(P \leq 0.01)$ from mother tree 1 $(98 \%)$ that consisted of inoculated seeds and were treated with Captan $^{\oplus}\left(\mathrm{T}_{3}\right)$ and also mother tree 2 $(88 \%)$ that had inoculated seeds and were subjected to the alternative control using $C$. ferrea extract $\left(T_{4}\right)$. It also appears that the worst germination and vigor performance was associated with the seeds from mother tree $6\left(T_{4}\right)$, regardless of the parameter evaluated in relation to the germination speed index

TABLE 1. Germination (\%) of Sideroxylon obtusifolium seeds, subjected to different treatments to control Colletotrichum sp.

\begin{tabular}{cccccc}
\hline \multirow{2}{*}{ Mother trees } & \multicolumn{5}{c}{ Treatments } \\
\cline { 2 - 6 } & $\mathbf{T}_{1}$ & $\mathbf{T}_{2}$ & $\mathbf{T}_{3}$ & $\mathbf{T}_{4}$ & $\mathbf{T}_{5}$ \\
\hline 1 & $95 \mathrm{aA}$ & $79 \mathrm{aB}$ & $98 \mathrm{aA}$ & $77 \mathrm{bB}$ & $15 \mathrm{aC}$ \\
2 & $90 \mathrm{baA}$ & $62 \mathrm{bB}$ & $89 \mathrm{bA}$ & $88 \mathrm{aA}$ & $20 \mathrm{aC}$ \\
3 & $93 \mathrm{baA}$ & $10 \mathrm{dC}$ & $42 \mathrm{~dB}$ & $36 \mathrm{cB}$ & $4 \mathrm{bC}$ \\
4 & $92 \mathrm{baA}$ & $57 \mathrm{bC}$ & $83 \mathrm{bB}$ & $20 \mathrm{dD}$ & $20 \mathrm{aD}$ \\
5 & $85 \mathrm{bA}$ & $45 \mathrm{cC}$ & $60 \mathrm{cB}$ & $18 \mathrm{dD}$ & $5 \mathrm{bD}$ \\
6 & $88 \mathrm{baA}$ & $38 \mathrm{cB}$ & $85 \mathrm{bA}$ & $0 \mathrm{eD}$ & $20 \mathrm{aC}$ \\
\hline CV (\%) & & 9.8 & & \\
\hline
\end{tabular}

"Means followed by the same letter, lowercase and uppercase in the column on the line, do not differ significantly at $1 \%$ probability $(\mathrm{P} \leq$ 0.01 ) by Tukey test.

$\mathrm{T}_{1}=$ untreated seeds and not inoculated, $\mathrm{T}_{2}=$ only inoculated seeds with Colletotrichum $\mathrm{sp} ., \mathrm{T}_{3}=$ inoculated seeds and fungicide treated, $\mathrm{T}_{4}=$ inoculated seeds and subjected to alternative control with $C$. ferrea extract, $\mathrm{T}_{5}=$ inoculated seeds and submitted the biological control with Trichoderma spp.

NOTE: Length of the seeds of different mother trees $\left(M_{1}-9.99 \mathrm{~cm}, M_{2}-9.94 \mathrm{~cm}, M_{3}-7.69 \mathrm{~cm}, M_{4}-7.51 \mathrm{~cm}, M_{5}-7.45 \mathrm{~cm}\right.$ and $\left.M_{6}-6.54 \mathrm{~cm}\right)$.

Rev. Bras. PI. Med., Campinas, v.18, n.2, p.494-501, 2016. 
of the S. obtusifolium seeds (Tables 1 and 2).

As for the germination speed index of all the mother trees (Table 2 ) the best results came from the untreated and uninoculated seeds shown in Table 1 $\left(T_{1}\right)$ however, there were no statistical differences ( $P$ $\leq 0.01$ ) between the inoculated seeds from mother tree 1 and 2, and the seeds subjected to chemical control $\left(T_{3}\right)$ and seeds from mother tree 2 treated with an alternative control, $C$. ferrea extract $\left(\mathrm{T}_{4}\right)$.

Similarly, the fungicide treatment with Captan $^{\circledR}$ and vegetal extract provided significant eradication of Colletotrichum sp. in seeds of Platypodium elegans Vog. (Machado, 2000) and Ceiba speciosa St. Hill. (Lazarotto et al., 2010), obtaining the highest percentage and germination speed index. In seeds of other native species like Tabebuia serratifolia (Vahl.) Nich. (Botelho et al., 2008) and Tabebuia impetiginosa (Mart. ex DC.) Standl. (Mertz et al., 2009), the chemical treatment constituted an efficient method to control pathogens associated with those seeds.

As for the C. Ferrea extract, it was discovered that the secondary metabolism of those species is a natural source of various chemical substances with anti-fungal properties. Among them are flavonoids, saponines, tannins and proteolytic inhibitors (Ferreira et al., 2013). Thus, the anti-fungal potential of $C$. ferrea extract in controlling pathogens such as Colletotrichum guaranicola and Fusarium oxysporum were described by Bariani et al. (2012), in studies with husk extracts of $C$. ferrea in the evaluation of sporulation and mycelial growth of fungi in vitro, confirming the results obtained in this study.

In general, the larger seeds of $S$. obtusifolium had a better germinative performance most likely because they have a lower imbibition rate and were well nourished during their development resulting in well-formed embryos with a higher quantity of substance storage, which are the reasons why their tissues are more resistant to deleterious actions caused by microorganisms that slowly colonize and consume them. These attributes contribute to the reason that these seeds expressed higher physiological qualities in relation to the mother trees consisting of smaller seeds. Similar results were obtained by Oliveira et al. (2003), when the influences of fungi and seed size on germination and vigor of Rheedia gardneriana (Planch \& Triana) were studied.

The germination percentage of inoculated and untreated seeds $\left(T_{2}\right)$ is in accordance with the data obtained by Medeiros et al. (2015), who found that the fungal infection in $C$. ferrea seeds severely affected the physiological quality of the seeds, and in some cases completely inhibited germination. Medeiros et al. (2013) also reported that Pterogyne nitens Tul. seeds which are predisposed to the action of microorganisms, reduce the survival rate of pathogens and enhance the percentage and germination rate when treated.

Thus, according to Cavalheiro et al. (2009), C. ferrea can be a new alternative in the search for active ingredients that are of interest to the biotechnology industry. With this in sight, more studies on the concentration and purification of compounds of the extract of this species is necessary. Hence, the use of products extracted from plants may be a viable alternative to control pathogens associated with seeds, with the added advantage of lessening the environmental impact of agrochemicals (Lazarotto et al., 2009).

Table 3 shows that the majority of the $S$. obtusifolium seed mother trees had higher values of symptomatic seedlings and the transmission rate of Colletotrichum sp. was higher in seeds that were only inoculated $\left(T_{2}\right)$ and subjected to treatment with

TABLE 2. Germination speed index (GSI) of Sideroxylon obtusifolium seeds, subjected to different treatments to control Colletotrichum sp.

\begin{tabular}{clllll}
\hline \multirow{2}{*}{ Mother trees } & \multicolumn{5}{c}{ Treatments } \\
\cline { 2 - 6 } & $\mathrm{T}_{1}$ & \multicolumn{1}{c}{$\mathrm{T}_{2}$} & \multicolumn{1}{c}{$\mathrm{T}_{3}$} & $\mathrm{~T}_{4}$ & \multicolumn{1}{c}{$\mathrm{T}_{5}$} \\
\hline 1 & $1.48 \mathrm{aA}$ & $0.55 \mathrm{baC}$ & $1.33 \mathrm{aA}$ & $0.97 \mathrm{bB}$ & $0.30 \mathrm{abD}$ \\
2 & $1.35 \mathrm{aA}$ & $0.71 \mathrm{aB}$ & $1.30 \mathrm{aA}$ & $1.21 \mathrm{aA}$ & $0.34 \mathrm{aC}$ \\
3 & $1.43 \mathrm{aA}$ & $0.20 \mathrm{cdCD}$ & $0.62 \mathrm{bB}$ & $0.32 \mathrm{cC}$ & $0.10 \mathrm{bcD}$ \\
4 & $1.46 \mathrm{aA}$ & $0.35 \mathrm{bcC}$ & $1.23 \mathrm{aB}$ & $0.23 \mathrm{dcC}$ & $0.10 \mathrm{bcD}$ \\
5 & $1.38 \mathrm{aA}$ & $0.35 \mathrm{bcC}$ & $0.83 \mathrm{bB}$ & $0.22 \mathrm{cdC}$ & $0.09 \mathrm{bcD}$ \\
& $1.44 \mathrm{aA}$ & $0.55 \mathrm{abC}$ & $1.10 \mathrm{aB}$ & $0.00 \mathrm{dE}$ & $0.33 \mathrm{aD}$ \\
\hline $\mathrm{CV}(\%)$ & & & 16.07 & &
\end{tabular}

'Means followed by the same letter, lowercase and uppercase in the column on the line, do not differ significantly at $1 \%$ probability $(\mathrm{P} \leq$ 0.01 ) by Tukey test.

$\mathrm{T}_{1}=$ untreated seeds and not inoculated, $\mathrm{T}_{2}=$ only inoculated seeds with Colletotrichum sp., $\mathrm{T}_{3}=$ inoculated seeds and fungicide treated, $\mathrm{T}_{4}=$ inoculated seeds and subjected to alternative control with $C$. ferrea extract, $\mathrm{T}_{5}=$ inoculated seeds and submitted the biological control with Trichoderma spp.

NOTE: Length of the seeds of different mother trees $\left(M_{1}-9.99 \mathrm{~cm}, M_{2}-9.94 \mathrm{~cm}, M_{3}-7.69 \mathrm{~cm}, M_{4}-7.51 \mathrm{~cm}, M_{5}-7.45 \mathrm{~cm}\right.$ and $\left.M_{6}-6.54 \mathrm{~cm}\right)$.

Rev. Bras. Pl. Med., Campinas, v.18, n.2, p.494-501, 2016. 
chemical fungicide $\left(T_{3}\right)$ making them stand out from the others where in mother trees 1,2 and with 36, 32 and $37 \%\left(\mathrm{~T}_{2}\right)$ and mother tree six with $30 \%\left(\mathrm{~T}_{3}\right)$ of the seeds contaminated also infected seedlings with transmission rates of $49,55,52$ and $39 \%$ respectively. It is also noted that Colletotrichum $\mathrm{sp}$. infected all of the seed lots except for those subjected to preventive treatments using $C$. ferrea extract $\left(\mathrm{T}_{4}\right)$ and Trichoderma spp. $\left(\mathrm{T}_{5}\right)$.

Symptoms caused by Colletotrichum sp., such as necrotic lesions in cotyledons, young leaves, roots and stem seedlings followed by their falling over were observed in the evaluation of sanitary and physiological quality, through the transmission rate achieved during the seed germination process of $S$. obtusifolium. Similar results were obtained by Seneme et al., (2012) when evaluating the influence of Colletotrichum sp. on the sanitary quality of Peltophorum dubium (Sprengel) Taubert. seeds, as well as by Lazarotto et al. (2010) during the seedling production of Ceiba speciosa A. St.-Hil. which initially found wounds in the cotyledons and later in the shoots, starting with the wilt apex seedling, stem strangulation and death of the seedling.

Given the results observed, Colletotrichum sp. possibly colonized the S. obtusifolium embryonic tissues and then transmitted it to the seedlings. It was found that by treating the plants or seeds using plant extract the seeds were greatly protected, this is probably because this defense treatment was conducted by systemic action through their inhibition. According to Vechiato \& Parisi (2013), this can be related to a possible intra-embryonic infection followed by a localized infection, since the symptoms appear during germination and the pathogen is driven by the cotyledons, causing symptoms in the shoots. The analysis of germination characteristics and sanity of forest seeds is an important factor, since there are few studies about this, especially with native species which are used in the process of forest restoration (Fantinel et al., 2013).

Several studies on forest species confirmed the seedling seed transmission of Colletotrichum sp. Lazarotto et al. (2010) studied the detection and fungal transmission on C. speciosa seeds and Vechiato \& Parisi (2013) evaluated the influence of Colletotrichum sp., in the sanitary and physiological seed quality of Lithraea brasiliensis March., Myracrodruon urundeuva Fr. All., T. impetiginosa Mart. ex DC. Standl., Apeiba tibourbou Aubl., C. fissilis Vell. and Dalbergia nigra (Vell.) Allemão ex Benth. the destructive effects caused by this pathogen were noted and in some cases completely inhibited seed germination.

Different results from those detected in this study were reported by Oliveira et al. (2003), who compared control methods for Peltophorum dubium (Spreng.) Taub. seeds controlling Aspergillus niger, Colletotrichum sp. and Fusarium sp. where it was detected that the percentage of infected seeds did not affect germination, but this association may allow the survival of the fungus and its dissemination. In other hosts plant, such as Blepharocalyx salicifolius (H.B.K.) Berg. (Rego et al., 2012) and C. speciosa (Lazarotto et al., 2010), symptoms caused by Colletotrichum sp. to the seedlings have not been verified. According to the first author, even though fungal transmission from the seeds to the seedlings was not observed, it is known that fungi can cause damage both in storage, at germination and during subsequent growth stages.

However, similar results from those detected

TABLE 3. Percentage of symptomatic seedlings (SS) and transmission rate (TR) of pathogens in seeds of Sideroxylon obtusifolium seeds, subjected to different treatments to control Colletotrichum sp.

\begin{tabular}{|c|c|c|c|c|c|c|c|c|}
\hline \multirow{4}{*}{ Mother trees } & \multicolumn{8}{|c|}{ Symptomatic seedlings and Transmission rate (\%) } \\
\hline & \multicolumn{8}{|c|}{ Treatments } \\
\hline & \multicolumn{2}{|c|}{$T_{2}$} & \multicolumn{2}{|c|}{$\mathbf{T}_{3}$} & \multicolumn{2}{|c|}{$\mathbf{T}_{4}$} & \multicolumn{2}{|c|}{$T_{5}$} \\
\hline & SS & TR & SS & TR & SS & TR & SS & TR \\
\hline 1 & 36 aA & $49 \mathrm{aA}$ & $5 \mathrm{eB}$ & $12 \mathrm{cdB}$ & $0 \mathrm{aC}$ & $0 \mathrm{aC}$ & $0 \mathrm{aC}$ & $0 \mathrm{aC}$ \\
\hline 2 & $32 \mathrm{abA}$ & $55 \mathrm{aA}$ & $11 \mathrm{~dB}$ & $20 \mathrm{bcB}$ & $0 \mathrm{aC}$ & $0 \mathrm{aC}$ & $0 \mathrm{aC}$ & $0 \mathrm{aC}$ \\
\hline 3 & $4 \mathrm{deB}$ & $6 \mathrm{~dB}$ & $23 \mathrm{bA}$ & $24 \mathrm{bA}$ & $0 \mathrm{aB}$ & $0 \mathrm{aB}$ & $0 \mathrm{aB}$ & $0 \mathrm{aB}$ \\
\hline 4 & $13 \mathrm{cA}$ & $17 \mathrm{cA}$ & $15 \mathrm{cdA}$ & 20 bcA & $0 \mathrm{aB}$ & $0 \mathrm{aB}$ & $0 \mathrm{aB}$ & $0 \mathrm{aB}$ \\
\hline 5 & $37 \mathrm{aA}$ & $52 \mathrm{aA}$ & 17 cB & $24 \mathrm{bB}$ & $0 \mathrm{aC}$ & $0 \mathrm{aC}$ & $0 \mathrm{aC}$ & $0 \mathrm{aC}$ \\
\hline 6 & $29 \mathrm{bA}$ & $38 \mathrm{bA}$ & $30 \mathrm{aA}$ & 39 aA & $0 \mathrm{bB}$ & $0 \mathrm{aB}$ & $0 \mathrm{aB}$ & $0 \mathrm{aB}$ \\
\hline CV $(\%)$ & & & & & & & & \\
\hline
\end{tabular}

"Means followed by the same letter, lowercase and uppercase in the column on the line, do not differ significantly at $1 \%$ probability $(\mathrm{P} \leq$ $0.01)$ by Tukey test.

$\mathrm{T}_{2}=$ only inoculated seeds with Colletotrichum sp., $\mathrm{T}_{3}=$ inoculated seeds and fungicide treated, $\mathrm{T}_{4}=$ inoculated seeds and subjected to alternative control with $C$. ferrea extract, $\mathrm{T}_{5}=$ inoculated seeds and submitted the biological control with Trichoderma spp.

NOTE: Length of the seeds of different mother trees $\left(M_{1}-9.99 \mathrm{~cm}, M_{2}-9.94 \mathrm{~cm}, M_{3}-7.69 \mathrm{~cm}, M_{4}-7.51 \mathrm{~cm}, M_{5}-7.45 \mathrm{~cm}\right.$ and $\left.M_{6}-6.54 \mathrm{~cm}\right)$.

Rev. Bras. PI. Med., Campinas, v.18, n.2, p.494-501, 2016. 
in this study were reported by Pedro et al. (2012), according to these authors, the efficiency of chemical fungicides and some other formulas based on Trichoderma harzianum reduced the incidence of pathogens such as Colletotrichum sp. however, Ferreira et al. (2013) verified that the antifungal effect of $C$. ferrea extract on controlling $C$. lindemuthianum and $C$. truncatum, confirming the results obtained in the research with S. obtusifolium.

\section{CONCLUSION}

Biological control with Trichoderma spp. and the alternative test with $C$. ferrea extract provide greater protection to the seed and seedling of $S$. obtusifolium to the transmissibility of Colletotrichum $\mathrm{sp}$., been the treatment based on the plant extract the most effective for this purpose, but only in larger seeds for not interfering in the germination percentage and speed.

\section{REFERENCES}

BARNETT H.C.; HUNTER B.B. Illustrated genera of imperfect fungi. 3rd ed. Mineapolis: Burgess Publishing, 1972. 241p.

BARIANI, A. et al. Partial purification of trypsin inhibitors from Caesalpinia ferrea and Swartzia polyphylla seeds and effect of protein extracts on pathogenic fungi. Summa phytopathologica, v.38, n.2, p.131-138, 2012.

BELTRÃO, A.E.S. et al. In vitro biomass production of Sideroxylon obtusifolium (Roem \& Schult). Revista Brasileira de Farmacognosia, v.18, n.1, p.696-698, 2008.

BOTELHO, L.S. et al. Fungi associated to the seeds of ipêamarelo (Tabebuia serratifolia) and ipê-roxo (Tabebuia impetiginosa): incidence, germination effect and seedlings transmission. Summa Phytopathologica, v.34, n.4, p.343-348, 2008.

BRASIL. Ministério da Agricultura, Pecuária e Abastecimento. Manual de análise sanitária de sementes. Brasília: SDA/CGAL, 2009. 202p.

CAVALHEIRO, M.G. et al. Biological and enzymatic activities of aqueous extract of seeds from Caesalpinia ferrea Mart., Leguminosae. Revista Brasileira de Farmacognosia, v.19, n.2, p.586-591, 2009.

FANTINEL, V.S. et al. Detection of fungi and transmission of Alternaria alternata by seeds of golden trumpet tree Handroanthus chrysotrichus (Mart. Ex D.C.) Mattos. Revista de Ciências Ambientais, v.7, n.2, p.6-14, 2013.

FERRAZ, I.D.K.; CALVI, D.P. Teste de germinação. In: LIMA-JUNIOR, M.J.V. (Ed.). Manual de procedimentos para análise de sementes florestais. Manaus: UFAM, 2010. p.55-110.

FERREIRA, M.R.A. et al. Antifungal activity of medicinal plants from Northeastern Brazil. Journal of Medicinal Plants Research, v.7, n.40, p.3008-3013, 2013.

FERREIRA, M.R.A.; SOARES, L.A.L. Libidibia ferrea (Mart. ex Tul.) L. P. Queiroz: a review of the biological activities and phytochemical composition. Journal of Medicinal Plants Research, v.9, n.5, p.140-150, 2015. GOMES, R. et al. Floral biology of Manilkara subsericea and Sideroxylon obtusifolium (Sapotaceae) in restinga. Revista Brasileira de Botânica, v.33, n.2, p.271-283, 2010.

LABOURIAU, L.G. A germinação de sementes. Washington: OEA, 1983. 174p.

LAZAROTTO, M. et al. Alternative treatments for control of pathogens on Cedrela fissilis seeds. Revista Brasileira de Agroecologia, v.4, n.2, p.75-78, 2009.

LAZAROTTO, M. et al. Detection, transmission, pathogenicity and chemical treatment of fungi in Ceiba speciosa seeds. Summa Phytopathologica, v.36, n.2, p.134-139, 2010.

MACHADO, J.C. Tratamento de sementes no controle de doenças. LAPS: UFLA: FAEPE, Lavras, 2000. 138p.

MAGUIRE, J.D. Speed of germination-aid selection evolution for seedling emergence and vigor. Crop Science, v.2, n.2, p.176-177, 1962.

MARREIRO, R.O. et al. Evaluation of the stability and antimicrobial activity of an ethanolic extract of Libidibia ferrea. Journal of Clinical, Cosmetic and Investigational Dentistry, v.6, n.7, p.9-13, 2014.

MEDEIROS, J.G.F. et al. Vegetable extracts on the control of pathogens in seeds of Pterogyne nitens Tul. Floresta e Ambiente, v.20, n.3, p.384-390, 2013.

MEDEIROS, J.G.F. et al. Sanitary quality of Caesalpinia ferrea seeds: incidence of fungi, control and effects on physiological quality with the use of plant extracts. Floresta, v.45, n.1, p.163-174, 2015.

MERTZ, L.M. et al. Bioprotectors and chemical fungicides in the treatment of soybean seeds. Ciência Rural, v.39, n.1, p.13-18, 2009.

MONDEGO, J.M. et al. Alternative control of microflora on Pseudobombax marginatum seeds with essential copaiba oil (Copaifera sp.). Bioscience Journal, v.30, n.2, p.349-355, 2014.

OLIVEIRA, P.A. et al. Metabolite profiling of the leaves of the Brazilian folk medicine Sideroxylon obtusifolium. Planta Medica, v.78, n.7, p.703-710, 2012.

OLIVEIRA, L.M. et al. Evaluation of methods for dormancy breaking and disinfestation of canafístula seeds (Peltophorum dubium (Sprengel) Taubert Caesalpinoideae. Revista Árvore, v.27, n.5, p.597603, 2003.

PEDRO, E.A.S. et al. Plant growth promotion of common bean and anthracnose control by Trichoderma spp. Pesquisa Agropecuária Brasileira, v.47, n.11, p.15891595, 2012.

POLETTO, T. et al. Fungos associados às flores e sementes da nogueira-pecã (Carya illinoinensis). Revista de Ciências Ambientais, v.8, n.1, p.5-13, 2014.

REGO, S.S. et al. Detection, transmission and pathogenicity of fungi on Blepharocalyx salicifolius (H.B.K.) Berg. seeds. Revista Brasileira de Sementes, v.34, n.1, p.9-13, 2012.

SAS/STAT User's Guide. In: SAS INSTITUTE. SAS online Doc. Version 8.2. Cary, 2011.

SENEME, A.M. et al. Germination, sanitary quality and storage of seeds of Peltophorum dubium (Spreng) Taub. Revista Árvore, v.36, n.1, p.1-6, 2012. 
STANGE, V.S. et al. Evaluation of mutagenic effect of crude hydroalchoolic extract, using in vivo alive bioassays and phytochemical screening of Cecropia glaziovii Sneth (embaúba), Cecropiaceae. Revista Brasileira de Farmacognosia, v.19, n.2, p.637-642, 2009.

SILVA, F.F.S.; DANTAS, B.F. Efeito da temperatura na germinação de sementes de Sideroxylon obtusifolium (Sapotaceae) de diferentes procedências. Revista SODEBRAS, v.8, n.90, p.40-43, 2013.

SILVA, K.B. et al. Morphological characterization of fruits, seeds and germination of Sideroxylon obtusifolium (Roem e Schult.) Penn. (Sapotaceae). Revista Árvore, v.36, n.1, p.59-64, 2012a.
SILVA, C.L. et al. Essential oils and plant extracts on the control of soft rot of crispy lettuce. Horticultura Brasileira, v.30, n.4, p.632-638, 2012b.

TEIXEIRA, H.; MACHADO, J.C. Transmissibility and effect of Acremonium strictum in maize seeds. Ciência e Agrotecnologia, v.27, n.5, p.1045-1052, 2003.

VECHIATO, M.H.; PARISI, J.J.D. Importance of sanitary quality of seeds in forestry seedling production. Revista do Instituto Biológico, v.75, n.1, p.27-32, 2013.

WALKER, C. et al. Transmission and pathogenicity of Phomopsis sp. associated with seeds of angicovermelho (Parapiptadenia rigida Benth.). Floresta e Ambiente, v.20, n.2, p.216-222, 2013. 